\title{
UIMC1 wt Allele
}

National Cancer Institute

\section{Source}

National Cancer Institute. UIMC1 wt Allele. NCI Thesaurus. Code C124099.

Human UIMC1 wild-type allele is located in the vicinity of 5 q35.2 and is approximately 118 $\mathrm{kb}$ in length. This allele, which encodes BRCA1-A complex subunit RAP80 protein, plays a role in DNA damage responses and binding to ubiquitinated histones. 